\title{
Cryopreservation of Seeds and Embryos of Jatropha curcas L.
}

\author{
Julián Andrés Prada1, María Elena Aguilar², Ana Abdelnour-Esquivel3, Florent Engelmann ${ }^{4}$ \\ ${ }^{1}$ Egresado Escuela de Posgrado del CATIE, Cartago, Costa Rica \\ 2Laboratorio de Biotecnología, Centro Agronómico Tropical de Investigación y Enseñanza (CATIE), Cartago, \\ Costa Rica \\ ${ }^{3}$ Centro de Investigación en Biotecnología, Instituto Tecnológico de Costa Rica (ITCR), Cartago, Costa Rica \\ ${ }^{4}$ IRD, UMR DIADE, Montpellier, France \\ Email: jprada@catie.ac.cr, aguilarm@catie.ac.c, aabdelnour@itcr.ac.cr, florent.engelmann@ird.fr
}

Received 23 December 2014; accepted 7 January 2015; published 15 January 2015

Copyright (C) 2015 by authors and Scientific Research Publishing Inc.

This work is licensed under the Creative Commons Attribution International License (CC BY).

http://creativecommons.org/licenses/by/4.0/

(c) (;) Open Access

\begin{abstract}
Jatropha curcas is a species with a variety of uses. It is grown primarily for oil for biodiesel, but also has agronomic and medicinal applications. Two methods were evaluated for cryopreservation of seeds and zygotic embryos of $J$. curcas: desiccation followed by rapid immersion of seeds and embryos in liquid nitrogen ( $\left.\mathrm{LN},-196^{\circ} \mathrm{C}\right)$, and vitrification of zygotic embryos. Prior to cryopreservation, seeds were manually scarified and the moisture content (MC) of seeds and embryos was determined. Explants were disinfected after cryopreservation. Seed germination after LN exposure was $100 \%$. Plantlet development was better in sand substrate than that in vitro. Survival of zygotic embryos after cryopreservation was also $100 \%$, without significant differences between treatments. Optimal development $(100 \%)$ and plantlet length $(51.77 \mathrm{~mm})$ were observed with embryos dried for $60 \mathrm{~min}$ to $9.4 \%$ MC under laminar flow prior to cryopreservation. Zygotic embryos subjected to the vitrification procedure did not withstand LN exposure. Survival data for non-cryopreserved embryos after each step of the vitrification procedure provided information about embryo tolerance to cryoprotectants.
\end{abstract}

\section{Keywords}

Cryopreservation, Seeds, Embryos, Dehydration, Vitrification, Desiccation

\section{Introduction}

Jatropha curcas is a species native to Mexico and Central America [1]. It is currently grown in South America, the Caribbean and several countries in Africa, Asia and Oceania [2] and is generally found at elevations below

How to cite this paper: Prada, J.A., Aguilar, M.E., Abdelnour-Esquivel, A. and Engelmann, F. (2015) Cryopreservation of Seeds and Embryos of Jatropha curcas L. American Journal of Plant Sciences, 6, 172-180. 
1200 meters above sea level [3]. The ideal temperature for growth is between $18^{\circ} \mathrm{C}$ and $28.5^{\circ} \mathrm{C}$. It belongs to the Euphorbiaceae family, subfamily Crotonoideae [4] [5].

In addition to the production of oil for biodiesel, J. curcas is used for medical purposes as an antiseptic, anticoagulant [6] and laxative [1]. It is also used as an insecticide for control of pests in cotton, corn, tomato and potato, and as a fertilizer. The seed cake after oil extraction has a nitrogen content of $3.2 \%$ to $3.8 \%$ and can be used as an organic soil amendment [7].

$J$. curcas is generally propagated by seed. Vegetative propagation has been reported to reduce longevity and seed production, thereby affecting oil yields [8]. Although some authors suggest that seeds of this species are orthodox [9], others report a 50\% loss of viability after storage for 15 months [10]. The use of the biotechnological tools of micropropagation and cryopreservation may improve the possibilities for multiplication of genotypes of interest and long-term conservation of germplasm of this species.

Cryopreservation consists of the storage of biological material in liquid nitrogen ( $\left.\mathrm{LN},-196^{\circ} \mathrm{C}\right)$ [11]. At this temperature, all cell divisions and metabolic processes are arrested. The plant material can thus be conserved for extended periods, without alteration or modification [12]. Cryopreservation protocols have been developed for a broad range of explants including seeds, zygotic embryos, shoot tips, somatic embryos, callus and cell suspensions [11] [13].

The objective of the present study was to establish cryopreservation protocols for seeds and zygotic embryos of Jatropha curcas.

\section{Materials and Methods}

Seeds and zygotic embryos were used in cryopreservation experiments. Desiccation followed by rapid cooling was tested with whole seeds and isolated zygotic embryos, while the vitrification technique was experimented with zygotic embryos [14] [15].

\subsection{Desiccation and Rapidcooling of Seeds}

Mature seeds of J. curcas were provided by the Forest Seed Bank (BSF) of the Tropical Agricultural Research and Higher Education Center (CATIE) located in Turrialba, Costa Rica. Seeds were dried under environmental conditions $\left(27^{\circ} \mathrm{C}, 85 \%\right.$ humidity) for 1 week at the BSF-CATIE facility. Seed moisture content (MC) prior to cryopreservation treatments was determined using the following formula:

$$
M C=\frac{F W-D W}{F W} \times 100 \quad[16]
$$

where fresh weight (FW) corresponds to the weight of the seeds after drying under ambient conditions, and dry weight (DW) refers to the seed weight after oven drying at $107^{\circ} \mathrm{C}$ for $17 \mathrm{~h}$.

Seeds were manually scarified to eliminate the testa and placed in cryotubes, with three replicates of 10 seeds per tube. The cryotubes were immersed directly in LN. Seeds used as controls $(-N L)$ were not immersed in LN. Cryotubes were retrieved from LN after 24 hand rewarmed for $2 \mathrm{~min}$ in a water-bath at $40^{\circ} \mathrm{C}$. After rewarming, seeds were disinfected for $30 \mathrm{~min}$ in a $3.5 \%$ sodium hypochlorite solution and rinsed three times with sterile water prior to planting. Growth recovery was evaluated in vitro and in a germination chamber. Seeds were planted in sand in plastic boxes and placed in a growth chamber for 2 weeks under continuous light at $30^{\circ} \mathrm{C} \pm$ $1{ }^{\circ} \mathrm{C}$ and $90 \%$ relative humidity. For in vitro germination, seeds were placed in culture tubes containing $100 \%$ MS medium [17] supplemented with $30 \mathrm{~g} / \mathrm{L}$ sucrose and $7 \mathrm{~g} / \mathrm{L}$ agar. Culture were placed in a culture room at $29^{\circ} \mathrm{C} \pm 2{ }^{\circ} \mathrm{C}$ in the dark for 1 week, then cultured under light conditions with a photoperiod of $12 \mathrm{~h} \mathrm{light} / 12 \mathrm{~h}$ dark with a light intensity of $30.5 \mu \mathrm{mol} \cdot \mathrm{m}^{-2} \cdot \mathrm{s}^{-1}$. The effect of LN exposure was measured by the percentage germination and development, and length $(\mathrm{mm})$ of seedlings treated with liquid nitrogen $(+\mathrm{NL})$, compared to non-cryopreserved samples $(-\mathrm{NL})$. Three replicates of 10 seeds each were used for each treatment. A completely random design was used with a $2 \times 2$ factorial arrangement.

\subsection{Desiccation and Rapidcooling of Zygotic Embryos}

Zygotic embryos were isolated from seeds aseptically after scarification and disinfection as previously described. Embryos were then placed on Petri dishes (10 embryos per plate) and dried for 0, 30 or 60 min under the air current of a transfer hood. The effect of drying time on survival after LN exposure was evaluated. Three repli- 
cates of 10 embryos per treatment were used.

Embryomoisture content [16] was determined before and after desiccation in sterile laminar airflow. Dry weight (DW) was measured after desiccation and oven drying at $107^{\circ} \mathrm{C}$ for $17 \mathrm{~h}$.

After desiccation, embryos were placed in $2 \mathrm{ml}$ polypropylene cryotubes (10 embryos/tube) and immersed rapidly in LN, where they were stored for 5 days. Embryos were rewarmed by immersing the cryovials in a $40^{\circ} \mathrm{C}$ water-bath for 2 min.

Growth recovery was evaluated by placing the embryos on semisolid 100\% MS medium [17] with 3\% sucrose and $7 \mathrm{~g} / \mathrm{L}$ agar for germination. Cultures were placed in the dark for 2 weeks and then grown in a growth chamber with a photoperiod of $12 \mathrm{~h}$ light $/ 2 \mathrm{~h}$ dark at $29^{\circ} \mathrm{C} \pm 2{ }^{\circ} \mathrm{C}$ for 2 weeks. After 30 days of culture, germination (\%), development (\%) and length (mm) of seedlings, for different drying times (0, 30 or 60 min) of cryopreserved (+NL) and non-cryopreserved embryos (-NL) were evaluated. A completely random design with a 3 $\times 2$ factorial arrangement was used.

\subsection{Vitrification of Zygotic Embryos}

Embryos were preconditioned by culturing them for 15 days on semisolid 100\% MS medium supplemented with $0.3 \mathrm{M}$ sucrose. Then embryos were transferred to the same medium with increasing sucrose concentrations (0.3, 0.5, $0.75 \mathrm{M}$ ) and incubated for $24 \mathrm{~h}$ at each concentration. Vitrification was carried out in two steps: first, embryos were incubated for $20 \mathrm{~min}$ in loading solution (LS) [18] consisting of liquid germination medium supplemented with 2.0 M glycerol and 0.4 M sucrose. The LS was replaced with PVS2 vitrification solution (MS medium with $0.4 \mathrm{M}$ sucrose, 30\% glycerol (v/v), 15\% ethyleneglycol (v/v) and 15\% DMSO (v/v) [19]. Embryos were held for $15 \mathrm{~min}$ in one of the following concentrations of PVS2: $60 \%, 80 \%$ or $100 \%$. Both the LS and the vitrification solution were added at $0^{\circ} \mathrm{C}$ and the cryotubes containing embryos were kept on ice at $0^{\circ} \mathrm{C}$ during the whole process. Embryos in cryotubes were stored in LN for $24 \mathrm{~h}$, then rewarmed in a $40^{\circ} \mathrm{C}$ water-bath. The vitrification solution was removed immediately and embryos were washed twice for 2 min with a $1.2 \mathrm{M}$ sucrosesolution. For recovery, embryos were subcultured on $100 \%$ MS medium with $0.75 \mathrm{M}$ sucrose for $1 \mathrm{~h}$, then transferred to $100 \%$ MS medium with $0.3 \mathrm{M}$ sucrose for $24 \mathrm{~h}$, and finally subcultured on MS medium with 0.1 M sucrose in the dark for 1 week. The effect of PVS2 concentration on embryo survival was evaluated.

Three replicates were used for each treatment. Control replicates were included at each step in the procedure to evaluate the effect of each treatment on survival and growth recovery. A completely random design was used.

\subsection{Statistical Analyses}

Data were treated by analysis of variance (ANOVA), which was performed using Infostat Statistical Software [20]. The Fisher test was also used for comparing means $(\alpha=0.05)$. Variables were: embryo survival $(\%)$ after each phase of the procedure, embryo germination (\%) in the recovery phase and development (\%) and length (mm) of plantlets.

\section{Results}

\subsection{Desiccation and Rapid Cooling of Seeds}

The average moisture content (MC) of seeds used in the experiments was 7.4\% after drying under ambient conditions (10 seeds per experiment, each experiment was repeated five times). Germination of non-cryopre-served $(-\mathrm{LN})$ control seeds was $100 \%$ both in sand substrate in the germination chamber and in vitro on MS culture medium (Table 1). However, development and plantlet length were significantly higher in sand substrate com-

Table 1. Effect of liquid nitrogen exposure of Jatropha curcas seeds on germination, development and plantlet length. -LN: non-cryopreserved seeds; +LN: cryopreserved seeds.

\begin{tabular}{|c|c|c|c|c|}
\hline & Substrate & Germination (\%) & Development (\%) & Length (mm) \\
\hline$-\mathrm{LN}$ & $\begin{array}{c}\text { Sand } \\
\text { MS 100\% }\end{array}$ & $\begin{array}{l}100 \mathrm{a} \\
100 \mathrm{a}\end{array}$ & $\begin{array}{r}100 a \\
93.3 b\end{array}$ & $\begin{array}{l}195.3 \mathrm{a} \\
67.83 \mathrm{~b}\end{array}$ \\
\hline$+\mathrm{LN}$ & $\begin{array}{c}\text { Sand } \\
\text { MS 100\% }\end{array}$ & $\begin{array}{l}100 \mathrm{a} \\
100 \mathrm{a}\end{array}$ & $\begin{array}{l}100 a \\
86.6 c\end{array}$ & $\begin{array}{l}194.3 a \\
28.53 c\end{array}$ \\
\hline
\end{tabular}

Means with the same letter are not significantly different (LSD Fisher; $\mathrm{p} \leq 0.05$ ). 
paredin vitro conditions. Germination of cryopreserved seeds (+LN) was also $100 \%$ in sand substrate and plantlets reached an average length of $195 \mathrm{~mm}$ after 2 weeks, with no significant differences with respect to noncryopreserved controls. Likewise, germination in vitro of cryopreserved seeds was $100 \%$, and was not significantly different from the other treatments (Figure 1). A negative effect of in vitro culture on plant development was observed with both non-cryopreserved $(-\mathrm{LN})$ control seeds, which reached a mean length of $67 \mathrm{~mm}$, and cryopreserved seeds $(+\mathrm{LN})$ which reached an average length of $28.5 \mathrm{~mm}$ (Table 1).

\subsection{Desiccation and Cooling of Zygotic Embryos}

Moisture content (MC) of embryos before desiccation was $11.6 \%$. It reached $9.7 \%$ after drying for 30 min and $9.4 \%$ after $60 \mathrm{~min}$. Germination and development of non-cryopreserved embryos were similar regardless of their MC. Plantlets from non-cryopreserved embryos dried for 0, 30 and 60 min reached lengths of $51.6 \mathrm{~mm}, 51.1$ $\mathrm{mm}$ and $49.2 \mathrm{~mm}$, respectively (Table 2, Figure 2). Zygotic embryos withstood LN exposure, including those with higher MC (not dried), and no significant differences in germination were observed between treatments (100\% germination for all treatments). However, development and plant length were significantly lower when embryos had not been dehydrated before LN exposure (Table 2).

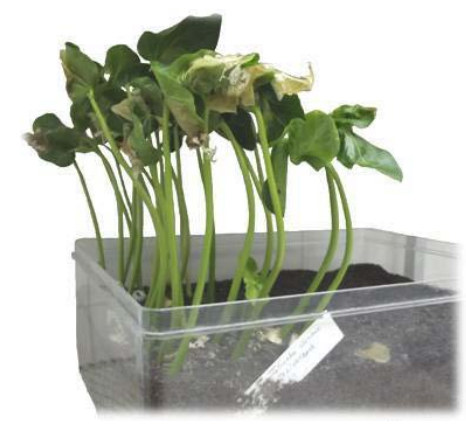

(a)

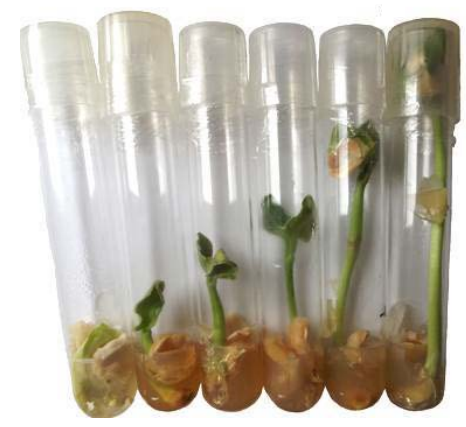

(c)

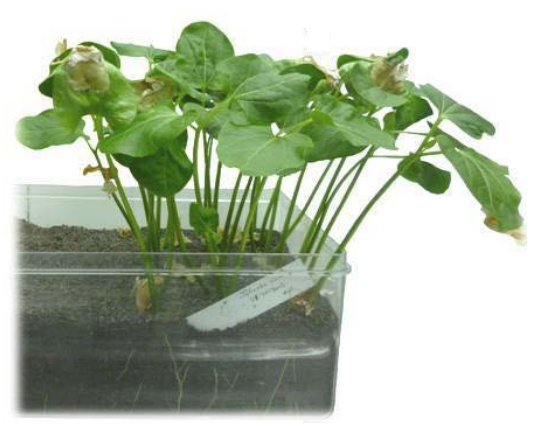

(b)

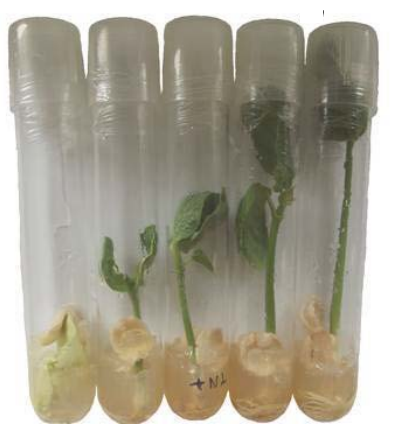

(d)

Figure 1. Germination and development of Jatropha curcas seeds: (a) Non-cryopreserved (-LN) seedsin sand substrate; (b) Cryopreserved seeds (+LN) in sand substrate; (c) Non-cryopreserved (-LN) seedsin vitro; (d) Cryopreserved seeds $(+\mathrm{LN})$ in vitro.

Table 2. Effect of drying time and of in liquid nitrogen exposure on germination of $J$. curcas zygotic embryos and development and length of plantlets. $-\mathrm{LN}$ : non-cryopreserved seeds; +LN: cryopreserved seeds.

\begin{tabular}{ccccc}
\hline & Drying time (min.) & Germination (\%) & Development (\%) & Length (mm) \\
\hline \multirow{2}{*}{-LN } & 0 & $100 \mathrm{a}$ & $100 \mathrm{a}$ & $51.67 \mathrm{a}$ \\
& 30 & $100 \mathrm{a}$ & $100 \mathrm{a}$ & $51.17 \mathrm{a}$ \\
+LN & $100 \mathrm{a}$ & $93.3 \mathrm{~b}$ & $49.20 \mathrm{a}$ \\
& 0 & $100 \mathrm{a}$ & $100 \mathrm{a}$ & $21.30 \mathrm{~b}$ \\
& 30 & $100 \mathrm{a}$ & $100 \mathrm{a}$ & $51.93 \mathrm{a}$ \\
\hline
\end{tabular}

Means with the same letter are not significantly different (LSD Fisher; $\mathrm{p} \leq 0.05)$. 


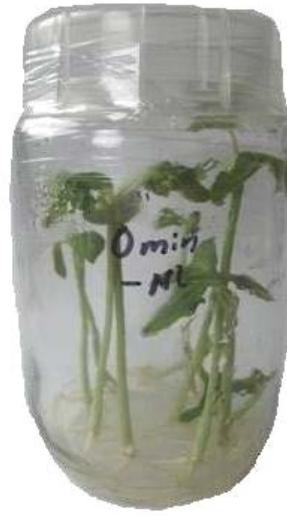

(a)

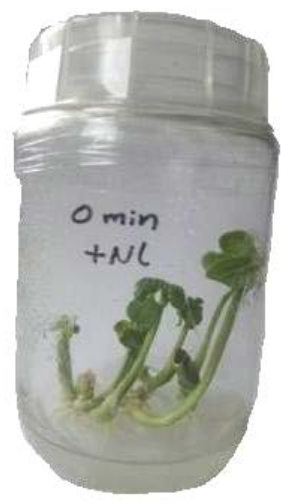

(c)

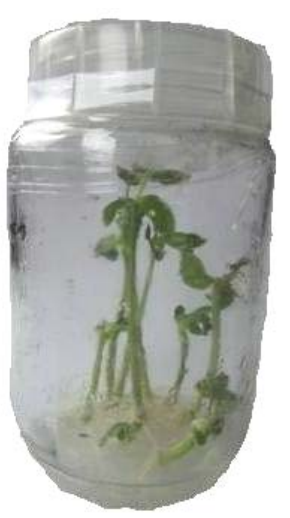

(b)

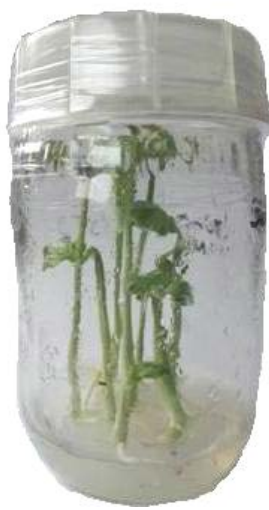

(d)

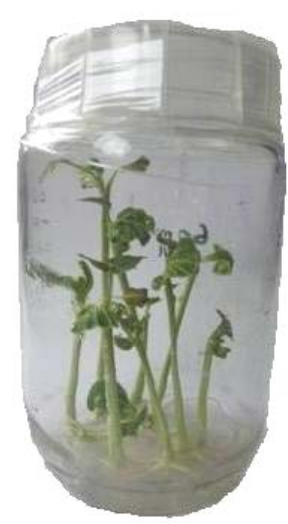

(c)

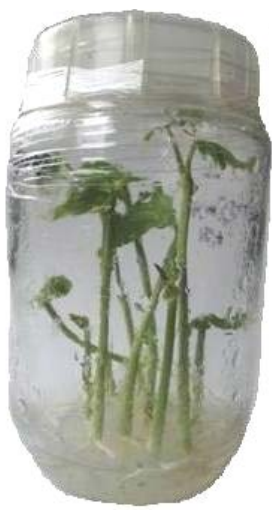

(e)

Figure 2. Germination and development of zygotic embryos of $J$. curcasafter desiccation and liquid nitrogen exposure. (a) 0 min of drying (-LN); (b) 30 min of drying ( $-\mathrm{LN})$; (c) 60 min of drying (-LN); (d) 0 min of drying (+LN); (e) 30 min of drying (+LN) and (f) 60 min of drying (+LN).

\subsection{Embryo Vitrification}

Zygotic embryos of $J$. curcas did not withstand cryopreservation using the vitrification procedure. Survival was $100 \%$ in untreated embryos, embryos precultured on $0.3 \mathrm{M}$ sucrose for 15 days and embryos pretreated with concentrations of $0.3,0.5$ or $0.75 \mathrm{M}$ sucrose (data not shown). The effect of high sucrose concentrations during pretreatment was noted in the survival, chlorosis and necrosis percentage of embryos after exposure to LS for 20 min (Table 3). Survival after incubation in LS was $100 \%$ for embryos pretreated with $0.3 \mathrm{M}$ sucrose and 93\% for those pretreated with $0.5 \mathrm{M}$ sucrose. Embryos pretreated with the highest sucrose concentration $(0.75 \mathrm{M})$ did not develop, and showed chlorosis (17\%) and tissue necrosis (83\%). Similar results were observed with embryos exposed to vitrification solutions atincreasing concentrations (60\%, 80\% and 100\% PVS2). Development was higher when embryos were pretreated with $0.3 \mathrm{M}$ sucrose and lower PVS2 concentrations (70\% and 60\% development of embryos exposed to $60 \%$ and $80 \%$ PVS2, respectively). Embryos pretreated with $0.75 \mathrm{M}$ sucrose showed the highest percentages of necrosis: $60 \%, 87 \%$ and $80 \%$ necrosis when treated with $60 \%, 80 \%$ or $100 \%$ PVS2, respectively (Table 3).

\section{Discussion}

Cryopreservation of plant material in the form of seeds, zygotic embryos and reproductive tissues is currently widely used [21]. Cryopreservation techniques for vegetatively propagated species are very advanced and there are an increasing number of cases of their large-scale use [15]. However, research in recalcitrant species cryopreservation is much less advanced due to seed characteristics such as large size, sensitivity to desiccation, struc- 
Table 3. Effect of sucrose pretreatment and exposure to loading and vitrification solutions on the response of $J$. curcas zygotic embryos.

\begin{tabular}{cccccc}
\hline & & \multicolumn{5}{c}{ Response of zygotic embryos } \\
\hline $\begin{array}{c}\text { Sucrose (M) } \\
\text { Pretreatment }\end{array}$ & Exposure to loading/vitrification solution & Development (\%) & Length (mm) & Chlorosis (\%) & Necrosis (\%) \\
\hline 0.3 & LS & 100.0 & 24.5 & - & - \\
0.5 & LS & 93.0 & 12.3 & - & 7.0 \\
0.75 & LS & 0.0 & 9.7 & 17.0 & 83.0 \\
0.3 & $60 \%$ PVS2 & 70.0 & 12.6 & 10.0 & 20.0 \\
0.3 & $80 \%$ PVS2 & 60.0 & 15.0 & 13.0 & 27.0 \\
0.3 & $100 \%$ PVS2 & 47.0 & 15.8 & 23.0 & 30.0 \\
0.5 & $60 \%$ PVS2 & 53.0 & 17.1 & - & 47.0 \\
0.5 & $80 \%$ PVS2 & 10.0 & 12.1 & 37.0 & 53.0 \\
0.5 & $100 \%$ PVS2 & 47.0 & 17.9 & 40.0 & 13.0 \\
0.75 & $60 \%$ PVS2 & 27.0 & 13.6 & 13.0 & 60.0 \\
\hline
\end{tabular}

tural complexity, heterogeneity in developmental stages, moisture content at maturity and the lack of functioning protocols for in vitro culture.

Information about the biology and conservation of $J$. curcas seeds remains limited and confusing. According to some authors [10] [22], seeds of this species cannot be stored for more than 15 months; others [23] claim that these seeds are orthodox and as such, can be stored with low water content. In addition, prolonged storage of these seeds may be limited by their high oil content [23]. This suggests that $J$. curcas seeds may be of intermediate storage behaviour. However, the classification of tropical seeds is not clear-cut, and some species initially considered recalcitrant are now grouped as intermediate or suborthodox [14]. Such is the case of coffee seeds (Coffea spp.), which can withstand LN exposure with a MC as low as 7\%, and are considered typical of intermediate seeds in terms of storage [24].

In the present study, germination of $J$. curcas seeds with a MC of $7.4 \%$ after drying indoors at ambient temperature and scarification was $100 \%$ after storage for $24 \mathrm{~h}$ in LN. Similarly, 59.8\% of seeds of this species with $4 \%-14 \%$ MC germinated after storage for 5 days in LN [24]. These authors suggest that seeds with $4 \%-8 \%$ MC can be stored in LN and maintain their physiological quality, with the upper limit of $8 \%$ being that of freshly collected seeds in the field.

Silva et al. [21] also used scarified J. curcas seeds and observed $82 \%$ germination after cryopreservation. However, seed MC was not reported. Growth recovery of other species, such as Swietenia macrophylla, considered to be recalcitrant, was $77 \%$ after slow cooling and immersion in LN of scarified seeds with a MC of $5.59 \%$ [25]. Seeds with and without testa of different species of the genus Swietenia were immersed directly in LN after drying at ambient temperature [26]. Survival was higher in scarifed seeds. Germination and development of seeds of S. macrophylla (MC 6.2\%) was $80 \%$ and $70 \%$, respectively. Germination of S. humillis (MC 6.1\%) and S. mahoganii (MC 5.3\%) was high (67\% and 73\%, respectively) and plant development was 67\% and $60 \%$, respectively, after direct immersion in LN. According to these authors, in the majority of cases, low germination (7\% - 17\%) was observed with seeds with testa, which are easily contaminated. The process of scarification, in addition to alleviating the germination barrier, allows selection of the best seed quality. Development of seeds of Toonaciliata cryopreserved by vitrification and rapid cooling in LN was 35\% [27]. However, the cryopreservation of fruits or seeds of Melia azedarach, which also belonged to the Meliaceae, was not successful [28].

In the present study, seed response was better in sand substrate compared to in vitro. Development of J. cur- 
cas seeds after immersion in LN was $100 \%$ in sand substrate and $86.6 \%$ in vitro. Length of plantlets grown in sand substrate or in vitro was 194 and $28 \mathrm{~mm}$, respectively. In contrast, seeds of Leucaena leucocephala responded better to inoculation in vitro after direct immersion in LN (24\% survival) while none of the seeds germinated in the greenhouse [26].

Cryopreservation of zygotic embryos of $J$. curcas by rapid cooling after dehydration under the laminar flow was successful in the present study. Survival and plant development was $100 \%$ when embryo MC was $9.7 \%$ and 9.4\%, which were achieved after 30 and 60 min of drying, respectively.

In other studies, zygotic embryos (MC 15\%) of Hieronyma alchorneoides did not withstand LN exposure without prior dehydration. However, drying of embryos for 15 - 60 min to 3\% - 4\% MC before cooling resulted in $2.7 \%$ - 5.3\% germination [29]. Dehydration of embryonic axes of mahogany (S. macrophylla) under the airflow of the laminarcabinet for $4 \mathrm{~h}$ resulted in a high percentage of germination and plantlet development (90\% and $76 \%$, respectively) using the encapsulation-dehydration technique [30]. Engelmann [12] highlighted the importance of artificial dehydration of explants prior to LN exposure as this protected against possible damage by intracellular crystallization of water into ice during cooling. However, intense dehydration may also cause damage to tissues due to the high concentration of intracellular salts and changes that these can cause in the cellular membrane [31].

Zygotic embryos cryopreserved using the vitrification technique did not withstand immersion in LN. There was a loss of survival of non-cryopreserved embryos with increasing concentrations of sucrose in the pretreatment medium $(0.5$ and $0.75 \mathrm{M})$ and after treatment with the LS and vitrification solutions. Similarly, the use of PVS2 for 20 min during vitrification of embryonic axes of Lansium domesticum did not affect survival when axes were precultured on MS medium with $0.3 \mathrm{M}$ sucrose for $16 \mathrm{~h}$ : however, axes did not withstand immersion in LN [32]. Chemical toxicity of cryoprotectants, osmotic pressure, water loss and especially the formation of intracellular ice crystals are among the most significant factors causing lethal damage during cryopreservation [11].

The comparison of the cryopreservation techniques tested in this study for $J$. curcas indicate that the most appropriate technique to use will depend on the objectives for cryopreservation and the form of subsequent growth recovery. Desiccation followed by directimmersion in LN of scarified seeds is a simple technique easy to perform in any laboratory or seed bank without requiring sophisticated equipment, as the only requirement is a LN storage tank. This technique would be less advantageous for storage of large volumes of seeds, as more space and LN would be required. Cryopreservation of isolated embryos is a more elaborate technique and as such requires more time and must be performed in a tissue culture laboratory. However, it may be an interesting option for the recovery of growth in vitro and could be used for further in vitro studies.

\section{Acknowledgements}

The authors thank the Costa Rican Ministry of Science and Technology and the National Council for Research in Science and Technology (MICIT-CONICIT), the Office of the Vice Chancellor for Research of the Technological Institute of Costa Rica (TEC) and the Tropical Agricultural Research and Higher Education Center (CATIE) for support received through funding of the project Cryopreservation of Woody Species, and the Forest Seed Bank of CATIE for providing seeds and laboratory facilities.

\section{References}

[1] Machado, R. and Suárez, J. (2009) Performance of Three Provenances of Jatropha curcas in the Germoplasm Bank of the EEPF "Indio Hatuey". Pastos y Forrajes, 32, 29-37.

[2] CATIE (Centro Agronómico Tropical de Investigación y Enseñanza) (2003) Arboles de Centroamérica: Un manual para extensionistas. Cordero, J. y Boshier, D. Turrialba, CR, 1079 p.

[3] Jiménez, R. and Martínez, G. (1994) Redescripción de Jatrophaandrieuxii Muell. Arg. (Euphorbiaceae), una especie endémica del sur de México. Acta Botánica Mexicana, 26, 27-32.

[4] Martínez, G., Jiménez, R., Cruz, R., Juárez, A., Garcia, R., Cervantes, A. and Mejía, R. (2002) Los géneros de la familia Euphorbiaceae en México. Anales del Instituto de Biología, UNAM. Ser Bot: UNAM Serie Botanica, 73, 155-281.

[5] Kone-Bamba, D., Pelissier, Y., Ozouko, Z. and Ouao, D. (1987) Etude de l'activité hémostatique de quinze plantes médicinales de la "Pharmacopée Traditionnelle Ivoirienne”. Plantes Médicinales et Phytothérapie, 21, 121-130. 
[6] Heller, J. (1996) Physic Nut. Jatropha curcas L. Promoting the Conservation and Use of Underutilized and Neglected Crops. 1. Institute of Plant Genetics and Crop Plant Research, Gatersleben/International Plant Genetic Resources Institute, Rome, 66 p.

[7] Grainge, M. and Ahmed, S. (1988) Handboook of Plants with Pest-Control Properties. John Wiley \& Sons, Hoboken, $470 \mathrm{p}$.

[8] Mukherjee, P., Varhney, A., Johnson, T.S. and Jha, T.B. (2011) Jatropha curcas: A Review on Biotechnological Status and Challenges. Plant Biotechnology Reports, 5, 197-215.

[9] Deng, Z.J., Xiang, Z.Y., Cheng, H.Y., Li, Y.J. and Song, S.Q. (2008) Preliminary Study on Development, Germination and Desiccation Tolerance of Jatropha curcas (Euphorbiaceae). Acta Botanica Yunnanica, 30, 355-359.

[10] Joker, D. and Jepsen, J. (2003) Jatropha curcas L. Seed Leaflet, No 83 August Danida Forest Seed Centre. Demark, 81-108.

[11] GonzalezArnao, M.T. and Engelmann, F. (2013) Introducción a la conservación ex situ de los recursos genéticos vegetales. In: GonzalezArnao, M.T. and Engelmann, F., Eds., Crioconservación de plantas en América Latina y el Caribe, Editorial Instituto Interamericano de Cooperación para la Agricultura, San José, 39-48.

[12] Engelmann, F. (1991) In Vitro Conservation of Tropical Plant Germplasm-A Review. Euphytica, 57, 227-243. http://dx.doi.org/10.1007/BF00039669

[13] Reed, B.M. (2008) Plant Cryopreservation: A Practical Guide. Springer, New York. http://dx.doi.org/10.1007/978-0-387-72276-4

[14] Hine-Gómez, A. and Abdelnour-Esquivel, A. (2013) Establecimiento in vitro de arándano (Vaccinium corymbosum L). Tecnología en Marcha, 26, 64-71.

[15] Engelmann, F. (2011) Use of Biotechnologies for the Conservation of Plant Biodiversity. In Vitro Cellular \& Developmental Biology —Plant, 47, 5-16. http://dx.doi.org/10.1007/s11627-010-9327-2

[16] International Seed Testing Association (ISTA) (2008) International Ruler For Seed Testing: The Germination Test. Seed Science and Technology, p. 7.

[17] Murashige, T. and Skoog, F. (1962) A Revised Medium for Rapid Growth and Bio Assays with Tobacco Tissue Cultures. Physiologia Plantarum, 15, 473-497. http://dx.doi.org/10.1111/j.1399-3054.1962.tb08052.x

[18] Matsumoto, T., Sakai, A. and Yamada, K. (1994) Cryopreservation of in Vitro Grown Apical Meristems of Wasabi (Wasabia japonica) by Vitrification and Subsequent High Plant Regeneration. Plant Cell Reports, 13, 442-446. http://dx.doi.org/10.1007/BF00231963

[19] Sakai, A., Kobayashi, S. and Oiyama, I. (1990) Cryopreservation of Nucellar Cells of Navel Orange (Citrus sinensis Osb. var. brasiliensis Tanaka) by Vitrification. Plant Cell Reports, 9, 30-33.

[20] Di Rienzo, J.A., et al. (2008) Infostat: Manual del usuario versión 2008. Coordinado por Di Rienzo, J.A.-1ed.-Brujas, Cordoba, ISBN 98-987-591-100-9.

[21] Silva, R., Camillo, J. and Pereira, S. (2012) A Method for Seedling Recovery in Jatropha curcas after Cryogenic Exposure of the Seeds. Revista de Biologia Tropical, 60, 473-482.

[22] Toral, O., Iglesias, J., Oca, S., Sotolongo, J., Garcia, S. and Torsti, M. (2008) Jatrpha curcas L., a Tree Species with Energetic Potential in Cuba. Pastos y Forrajes, 31, 191-207.

[23] Verma, K. and Gaur, A. (2009) Jatropha curcas L.: Substitute for Conservation Energy. World Journal of Agricultural Sciences, 5, 552-556.

[24] Abdelnour-Esquivel, A., Villalobos, V. and Engelmann, F. (1992) Cryopreservation of Zygotic Embryos of Coffea spp. Cryoletters, 13, 197-302.

[25] Normah, N., Choo, K., Yap, V. and Zeti, M. (2011) In Vitro Conservation of Malaysian Biodiversity-Archievements, Challenges and Future Directions. In Vitro Cellular \& Developmental Biology_Plant, 47, 26-36. http://dx.doi.org/10.1007/s11627-010-9306-7

[26] Abdelnour-Esquivel, A. and Aguilar, M.E. (2013) Crioconservación de germoplasma vegetal en Costa Rica. In: GonzalezArnao, M.T. and Engelmann, F., Eds., Crioconservación de plantas en America Latina y el Caribe, Editorial Instituto Interamericano de Cooperación para la Agricultura, San José, 113-126.

[27] Scocchi, A., Dieringer, E., Mroginski, E. and Mroginski, L. (2004) Conservación de semillas de cedro australiano (Toona ciliata). Plant Genetic Resources Newsletter, 137, 1-4.

[28] Scocchi, A.M. and Rey, H.Y. (2004) Conservación de germoplasma in vitro. In: Echenique, V., Rubinstein, C. and Mroginski, L., Eds., Biotecnología y mejoramiento vegetal, Ediciones INTA, Buenos Aires, 179-185.

[29] Abdelnour-Esquivel, A., Rojas, G. and Alfaro, U. (2007) Estudios preliminares para la crioconservación de especies forestales arbóreas. Tecnología en Marcha, 20, 98-103. 
[30] Aguilar, M.E. and Abdelnour-Esquivel, A. (2010) Desarrollo de modelos para la crioconservación de semillas y material clonal de especies forestales de Costa Rica en peligro de extinción y seleccionadas en programas de mejoramiento genético. Boletin de Ciencia y Tecnología No. 99, San José, CONICIT. http://163.178.205.6/boletin/boletin99/PalabrasMariaElenaAguilar.html

[31] Meryman, H.T., Williams, R.J. and Douglas, S.J. (1977) Freezing Injury from Solution Effects and Its Prevention by Natural or Artificial Cryoprotection. Cryobiology, 14, 287-302. http://dx.doi.org/10.1016/0011-2240(77)90177-8

[32] Goldfarb, M., Duarte, M. and Mata, M. (2010) Armazenamento criogênico de sementes de pinhão manso (Jatropha curcas L.) Euphorbiaceae. Revista Biotemas, 23, 27-33. 
Scientific Research Publishing (SCIRP) is one of the largest Open Access journal publishers. It is currently publishing more than 200 open access, online, peer-reviewed journals covering a wide range of academic disciplines. SCIRP serves the worldwide academic communities and contributes to the progress and application of science with its publication.

Other selected journals from SCIRP are listed as below. Submit your manuscript to us via either submit@scirp.org or Online Submission Portal.
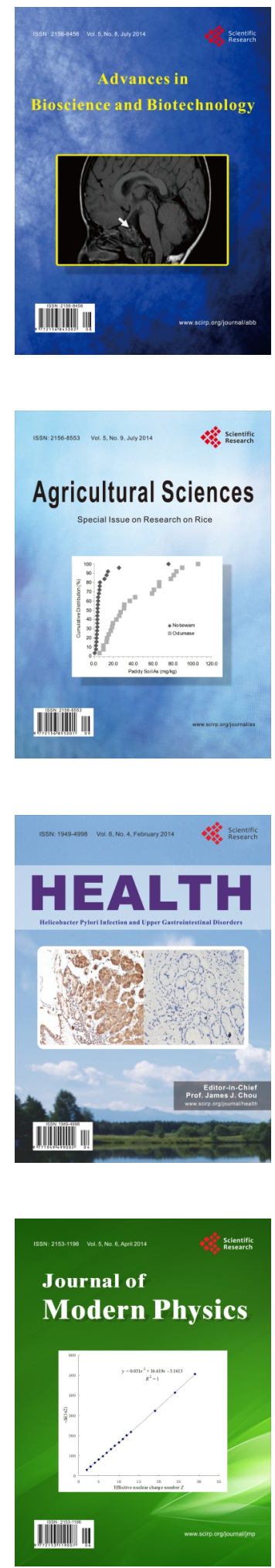
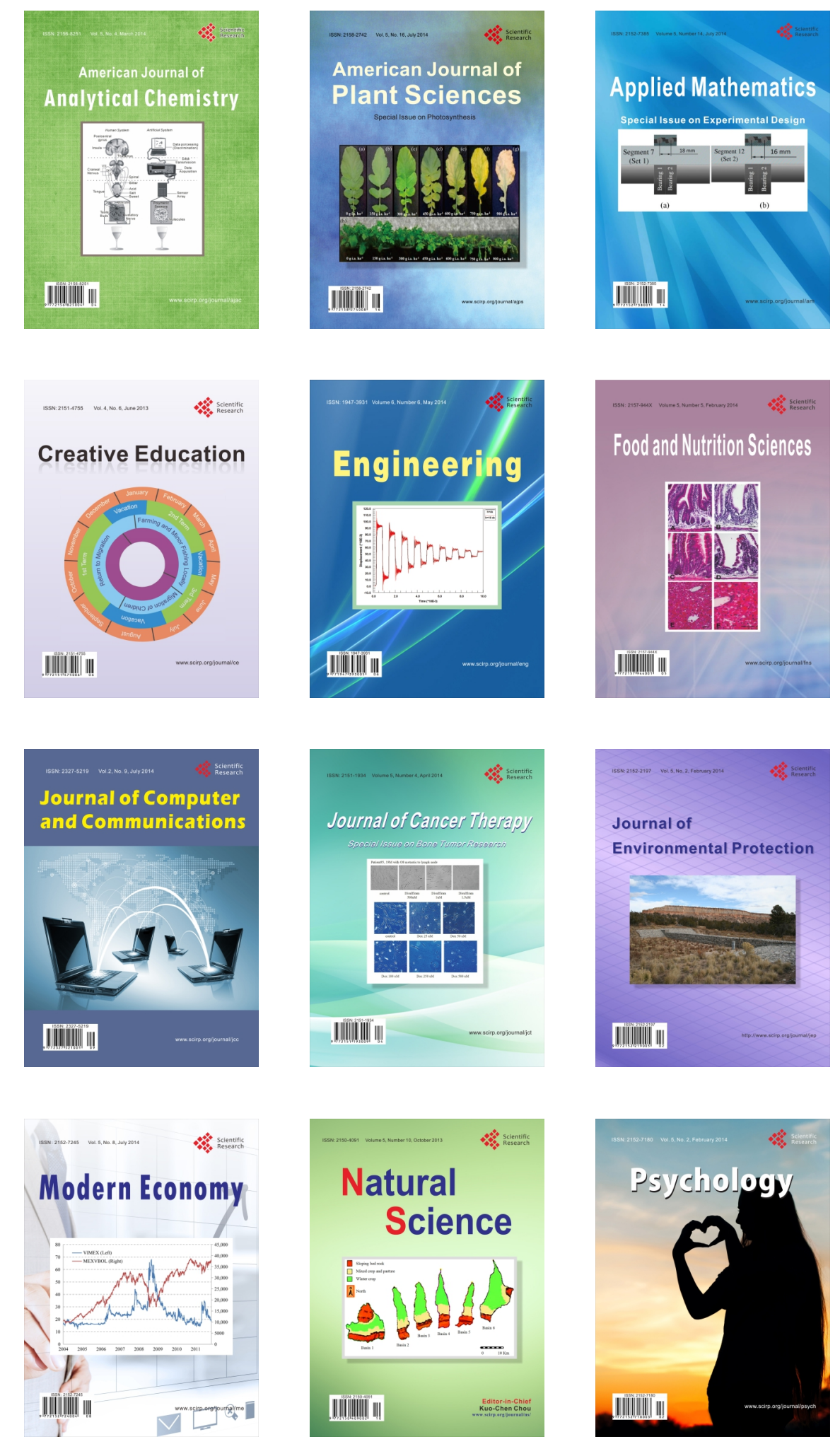